\title{
PENGARUH PERBANDINGAN TEMPURUNG KELAPA DAN ECENG GONDOK SERTA VARIASI UKURAN PARTIKEL TERHADAP KARAKTERISTIK BRIKET
}

\author{
Iriany, Firman Abednego Sarwedi Sibarani*, Meliza \\ DepartemenTeknik Timia, Fakultas Teknik, Universitas Sumatera Utara, \\ Jl. Almamater Kampus USU, Medan 20155, Indonesia \\ *Email: firman.abednego@gmail.com
}

\begin{abstract}
Abstrak
Penelitian ini menggunakan bahan baku eceng gondok dan tempurung kelapa. Tujuan penelitian ini adalah mendapatkan briket dengan nilai kalor tertinggi dan untuk mendapatkan briket dengan kualitas yang baik. Perbandingan antara eceng gondok dan tempurung kelapa pada penelitian ini adalah 1:1, 1:2, 1:3, 1:4 dengan variasi ukuran partikel sebesar 10 mesh, 42 mesh, dan 60 mesh serta menggunakan perekat tapioka $10 \%$ dari berat bahan baku. Hasil pengukuran pada penelitian ini dibandingkan dengan parameter mutu berdasarkan SNI, standar Jepang, Inggis, dan Amerika. Dari hasil penelitian ini diketahui bahwa komposisi briket yang terbaik diperoleh pada campuran eceng gondok dan tempurung kelapa pada perbandingan 1:4 dengan ukuran partikel 60 mesh yaitu dengan nilai kalor tertinggi sebesar 6.851,3311 $\mathrm{kal} / \mathrm{g}$, kadar abu terendah 8,1918\%, kadar air terendah 1,0140\%, kadar zat menguap 13,7890\%, nilai kerapatan $0,9836 \mathrm{~g} / \mathrm{cm}^{3}$, laju pembakaran $2,9 \times 10^{-3} \mathrm{~g} /$ detik dan kuat tekan $11,3234 \mathrm{~kg} / \mathrm{cm}^{2}$. Hasil ini telah memenuhi SNI, standar Jepang, Inggis, dan Amerika, sedangkan untuk kuat tekan briket hanya memenuhi standar Inggis.
\end{abstract}

Kata kunci: briket, eceng gondok, tempurung kelapa, tapioka, ukuran partikel

\begin{abstract}
This research used raw material water hyacinth and coconut shell. The purpose of this research is to get briquettes with high heating value and to obtain briquettes with good quality. Comparison of the base material mixed water hyacinth and coconut shell in this research is 1:1, 1:2, 1:3, 1:4 with variations in particle size of 10 mesh, 42 mesh and 60 mesh, and using an adhesive tapioca 10\% from the weight of raw material. The results of measurement in this research was compared to the quality parameters such as SNI, Japan standard, British, and America. The survey results revealed that the ideal composition made from a mixture of water hyacinth and coconut shell is briquette in comparison 1:4 with particle size 60 mesh and have the highest of heating value is $6.851,3311 \mathrm{cal} / \mathrm{g}$, the lowest ash content is $8,1918 \%$, the lowest of moisture content is 1,0140\%, levels of substance evaporates is $13,7890 \%$, the value of density is $0.9836 \mathrm{~g} / \mathrm{cm}^{3}$, the firing rate is $2,9 \times 10^{-3} \mathrm{~g} / \mathrm{sec}$ and the compressive strength is $11,3234 \mathrm{~kg} / \mathrm{cm}^{2}$. The results are in accordance to SNI, Japan standard, British, and America, while the compression pressure of briquette only accordance to British standard.
\end{abstract}

Keywords: briquette, water hyacinth, coconut shell, tapioca, particle size

\section{Pendahuluan}

Energi merupakan komponen utama dalam seluruh kegiatan makhluk hidup di bumi. Sumber energi yang utama bagi manusia adalah sumber daya alam yang berasal dari fosil. Sumber ini terbentuk berjuta-juta tahun yang lalu, sehingga energi ini lama-kelamaan akan habis. Hal ini membuat manusia mulai berusaha untuk mendapatkan energi alternatif sebagai pengganti energi dari bahan bakar fosil.

Usaha manusia dalam mencari pengganti sumber energi ini harus didasarkan pada bahan bakunya yang mudah diperoleh, bersifat dapat diperbaharui, dan produknya mudah dipergunakan oleh seluruh manusia. Krisis energi yang terjadi akhir-akhir ini menunjukkan bahwa konsumsi energi telah mencapai tingkatan yang cukup tinggi. Namun, seiring dengan meningkatnya kebutuhan sumber energi tersebut dapat menyebabkan habisnya sumber energi di dalam perut bumi karena tidak dapat diperbaharui [1].

Beberapa jenis sumber energi alternatif yang biasa dikembangkan antara lain energi matahari, energi angin, energi panas bumi, energi panas laut, dan energi biomassa. Diantara sumber-sumber energi alternatif tersebut, energi biomassa merupakan sumber energi alternatif yang perlu mendapat prioritas dalam pengembangan dibandingkan dengan sumber energi yang lain. Disisi lain, Indonesia sebagai negara agaris banyak menghasilkan limbah pertanian yang kurang termanfaatkan. Limbah pertanian yang merupakan biomassa tersebut merupakan sumber energi alternatif yang melimpah dengan kandungan energi yang relatif besar. Limbah pertanian tersebut dapat diolah menjadi suatu bahan bakar padat yang lebih luas penggunaannya sebagai bahan bakar alternatif yang disebut biobriket [2]. 


\section{Teori}

Briket merupakan suatu padatan yang dihaislkan melalui proses pemampatan atau pemberian tekanan, apabila dibakar akan menghasilkan sedikit asap. Adapun salah satu kelebihan briket tampak pada proses pembuatannya yang tidak terlalu sulit serta bahan baku pembuatan briket dapat dibuat dari bahan-bahan yang ada di lingkungan sekitar. Biomassa yang dapat dijadikan briket antara lain eceng gondok dan tempurung kelapa [4].

Eceng gondok (Eichornia Crossipes) merupakan tumbuhan air yang tumbuh di rawarawa, danau, waduk, dan sungai yang alirannya tenang. Berbagai masalah yang timbul dari pertumbuhan eceng gondok yang sangat cepat $(3 \%$ per hari), antara lain mempercepat pendangkalan sungai atau danau, menurunkan produksi ikan, mempersulit saluran irigasi, dan menyebabkan penguapan air 3 sampai 7 kali lebih besar dari pada penguapan air di perairan terbuka. Nilai kalor yang terkandung dalam eceng gondok pada umumnya berkisar 3.207,90 kal/g [3].

Tempurung merupakan lapisan yang keras dengan ketebalan antara $3 \mathrm{~mm}$ sampai $5 \mathrm{~mm}$. Sifat kerasnya disebabkan oleh banyaknya kandungan silikat $\left(\mathrm{SiO}_{2}\right)$ yang terdapat pada tempurung tersebut. Dari berat total buah kelapa, antara $15 \%$ sampai $19 \%$ merupakan berat tempurungnya. Selain itu tempurung juga banyak mengandung lignin. Sedang kandungan metoksil dalam tempurung hampir sama dengan yang terdapat dalam kayu [3].

Pada pembuatan briket, biomassa terlebih dahulu dikarbonisasi untuk dijadikan arang. Proses karbonisasi atau pengarangan adalah proses mengubah bahan baku menjadi karbon berwarna hitam melalui pembakaran dalam ruang tertutup dengan udara yang terbatas atau seminimal mungkin. Proses karbonisasi atau pengarangan bertujuan untuk menaikkan nilai kalor biomassa serta menghasilkan pembakaran yang bersih dengan sedikit asap. Hasil karbonisasi berupa arang yang tersusun atas karbon berwarna hitam [7].

Untuk merekatkan partikel-partikel zat dalam bahan baku pada proses pembuatan briket, diperlukan zat perekat sehingga dihasilkan briket yang mengikat. Dengan adanya penggunaan bahan perekat maka ikatan antar partikel akan semakin kuat, butir-butir arang akan saling menyatu, susunan partikel juga akan semakin baik sehingga dalam proses pengempaan briket akan semakin baik. Syarat utama dari bahan perekat adalah harus dapat ikut terbakar dan dapat menambah nilai kalor [1].

\section{Metodologi Penelitian}

Bahan-bahan yang digunakan dalam penelitian ini adalah eceng gondok, tempurung kelapa, tepung tapioka, dan air.
Alat-alat yang digunakan dalam penelitian ini adalah bomb calorimeter, oven, furnace, alat kempa briket, neraca, cetakan briket, ember, lumpang, ayakan ukuran 10 mesh, 42 mesh, dan 60 mesh, thermometer, penangas air, screening, hammer mill, dan gelas ukur $100 \mathrm{ml}$.

Variabel yang digunakan dalam penelitian ini meliputi variabel tetap dan variabel berubah.

- Variabel tetap

Varibel tetap merupakan varibel yang tetap atau tidak berubah dalam penelitian, yaitu: perekat tapioca $10 \%$, berat eceng gondok $20 \mathrm{~g}$, suhu karbonisasi eceng gondok dan tempurung kelapa $400^{\circ} \mathrm{C}$, dan pembuatan perekat tapioka dengan perbandingan tapioka dan air adalah 1:4.

- Variabel berubah

Variabel berubah merupakan variabel yang berubah sesuai dengan yang diinginkan dalam penelitian, yaitu ukuran partikel briket 10 mesh, 42 mesh, dan 60 mesh, perbandingan berat eceng gondok dan tempurung kelapa 1:1, 1:2, 1:3, dan 1:4.

Penelitian dilakukan dalam tiga tahapan, yaitu tahapan pembuatan arang, tahapan pembuatan briket arang, dan tahapan analisa meliputi analisa proksimat (nilai kalor, kadar abu, kadar air, dan kadar zat menguap), uji kerapatan, uji kekuatan tekan dan uji laju pembakaran.

\section{Prosedur Penelitian}

- Pembuatan arang

- Bahan baku eceng gondok dan tempurung kelapa dikeringkan terlebih dahulu lalu di cacah kecil-kecil.

- Eceng gondok dikarbonisasi di dalam furnace dengan suhu $400{ }^{\circ} \mathrm{C}$ selama 15 menit sedangkan tempurung kelapa dikarbonisasi di dalam furnace pada suhu $400{ }^{\circ} \mathrm{C}$ selama 1 jam untuk dijadikan arang.

- Pembuatan briket arang

- Arang eceng gondok dan tempurung kelapa yang telah dikarbonisasi digiling dengan hammer mill untuk dijadikan serbuk arang.

- Serbuk arang diayak dengan ukuran 10 mesh, 42 mesh, dan 60 mesh

- Lalu berat eceng gondok dan tempurung kelapa divariasikan yaitu 1:1, 1:2, 1:3, dan 1:4.

- Setelah divariasikan, eceng gondok dan tempurung kelapa dicampur dengan perekat tapioka sebanyak $10 \%$ dari berat bahan baku.

- Kemudian campuran tersebut dicetak menggunakan alat cetak briket dengan kekuatan tekan 1 ton $/ \mathrm{cm}^{2}$.

- Briket yang telah dicetak dikeringkan dan dianalisa karakteristiknya.

- Tahapan analisa

Analisa pada penelitian ini meliputi :

- Nilai kalor (Lab. Instrument PTKI Medan)

- Kadar abu (SNI 06-3730-1995) 
- Kadar air (SNI 06-3730-1995)

- Kadar zat menguap (SNI 06-3730-1995)

- Uji kerapatan (SNI 06-3730-1995)

- Uji kekuatan tekan (Lab. BKK PTKI Medan)

- Uji laju pembakaran (SNI 06-3730-1995)

\section{Hasil}

Data hasil penelitian yang diberikan adalah nilai dari pengujian masing-masing sampel briket yang meliputi nilai kalor, kadar abu, kadar air, kadar zat menguap, kerapatan, kekuatan tekan, dan laju pembakaran.

\section{Nilai Kalor}

Nilai kalor perlu diketahui dalam pembuatan briket, karena untuk mengetahui nilai panas pembakaran yang dapat dihasilkan oleh briket sebagai bahan bakar. Semakin tinggi nilai kalor yang dihasilkan oleh bahan bakar briket, maka akan semakin baik kualitasnya.

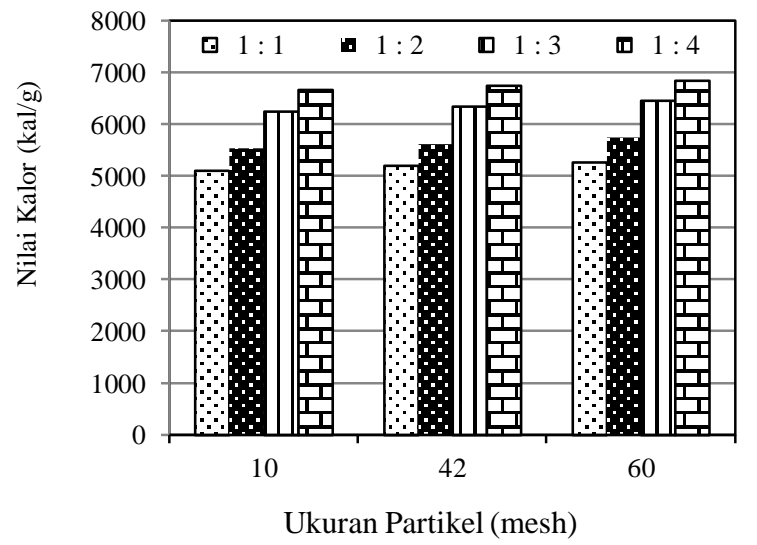

Gambar 1. Pengaruh Perbandingan Eceng Gondok dan Tempurung Kelapa Serta Ukuran Partikel Terhadap Nilai Kalor

Pada Gambar 1 dapat dilihat bahwa nilai kalor terendah diperoleh pada perbandingan eceng gondok dengan tempurung kelapa 1:1 dan pada ukuran partikel 10 mesh yaitu $5.102,9025 \mathrm{kal} / \mathrm{g}$, sedangkan nilai kalor tertinggi diperoleh dari perbandingan eceng gondok dengan tempurung kelapa 1:4 dan pada ukuran mesh 60 yaitu sebesar $6.851,3311 \mathrm{kal} / \mathrm{g}$.

Dari penelitian ini dapat dijelaskan bahwa semakin banyak jumlah tempurung kelapa yang ditambahkan maka semakin tinggi nilai kalor yang dihasilkan. Hal ini disebabkan nilai kalor dari tempurung kelapa yang lebih tinggi yaitu $7.345,9149 \mathrm{kal} / \mathrm{g}$ [5], sedangkan eceng gondok memiliki nilai kalor 3.207,90 kal/g [6]. Nilai kalor briket arang antara lain dipengaruhi oleh ukuran partikel arang, kerapatan arang dan bahan baku arang. Semakin kecil ukuran partikel maka nilai kalornya semakin tinggi, demikian juga semakin kecil ukuran partikel semakin tinggi pula kerapatannya [7].

\section{Kadar Abu}

Abu merupakan bagian yang tersisa dari hasil pembakaran dalam hal ini adalah sisa pembakaran briket arang. Salah satu unsur penyusun abu adalah silikat [2]. Pengaruhnya kurang baik terhadap nilai kalor briket arang yang dihasilkan. Kandungan abu yang tinggi dapat menurunkan nilai kalor briket arang sehingga kualitas briket arang tersebut menurun.

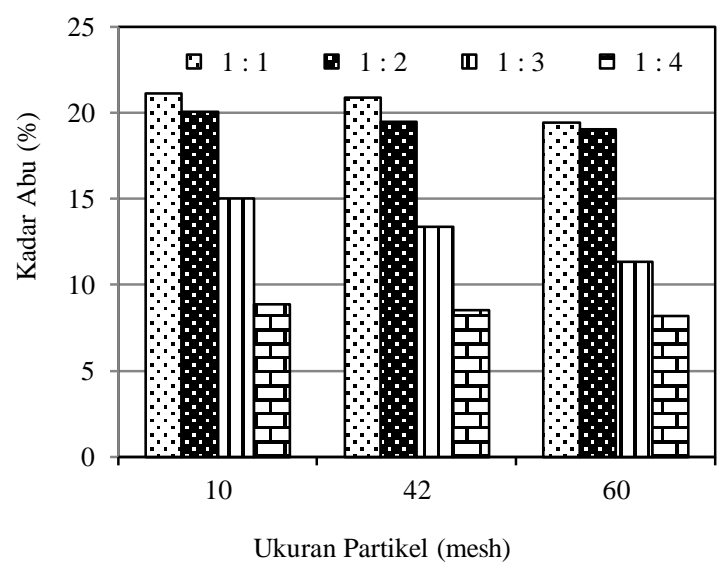

Gambar 2. Pengaruh Perbandingan Eceng Gondok dan Tempurung Kelapa Serta Ukuran Partikel Terhadap Kadar Abu

Pada Gambar 2 dapat dilihat nilai kadar abu terendah pada perbandingan eceng gondok dengan tempurung kelapa 1:4 dengan ukuran partikel 60 mesh yaitu $8,1918 \%$, sedangkan nilai kadar abu terbesar pada perbandingan 1:1 pada ukuran partikel 10 mesh yaitu 21,1588\%. Penambahan eceng gondok meningkatkan kadar abu pada briket arang. Hal ini disebabkan kandungan abu pada arang eceng gondok lebih tinggi yaitu $23,8 \%$ sedangkan kandungan abu pada arang tempurung kelapa yaitu $0,60 \%[2,3]$.

Ukuran partikel juga mempengaruhi kadar abu dari briket, semakin besar ukuran partikel briket maka kadar abunya juga semakin besar dan sebaliknya semakin kecil partikel briket maka kadar abu akan semakin kecil pula. Hal ini dapat dilihat pada saat briket dibakar sampai menjadi abu. Briket dengan ukuran partikel yang lebih besar akan menghasilkan abu yang lebih banyak dari pada briket yang ukuran partikelnya lebih kecil, karena pada proses pembakaran briket yang ukuran partikelnya kecil akan mudah terbawa oleh angin dan abu nya akan sedikit dihasilkan.

\section{Kadar Air}

Kadar air merupakan salah satu hal yang mempengaruhi kualitas dari briket, semakin besar kadar air di dalam briket maka kualitasnya semakin menurun, disebabkan nilai bakarnya akan menurun, atau sukar untuk dibakar. Begitu juga sebaliknya semakin kecil kadar air yang terkandung, maka semakin baik kualitas briket tersebut. Hal ini 
disebabkan panas yang diberikan digunakan terlebih dahulu untuk menguapkan air yang terkandung didalam briket

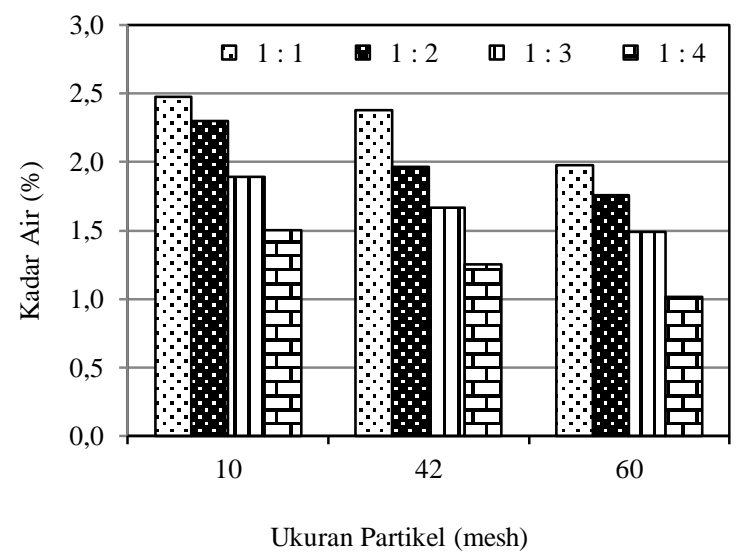

Gambar 3. Pengaruh Perbandingan Eceng Gondok dan Tempurung Kelapa Serta Ukuran Partikel Terhadap Kadar Air

Pada Gambar 3 dapat dilihat nilai kadar air terkecil diperoleh pada perbandingan 1:4 dengan ukuran partikel atau ukuran mesh 60 yaitu $1,0140 \%$. Sedangkan nilai kadar air terbesar diperoleh pada perbandingan 1:1 pada ukuran partikel 10 mesh yaitu $2,4936 \%$.

Dari penelitian ini dapat dijelaskan bahwa semakin besar ukuran partikel pada briket maka kadar airnya semakin besar dan mengurangi kualitas dari briket tersebut. Hal ini disebabkan ukuran partikel yang besar akan banyak menyerap air.

Penambahan tempurung kelapa juga mempengaruhi nilai kadar air. Semakin sedikit penambahan tempurung kelapa, maka kadar air akan semakin meningkat. Hal ini disebabkan kadar air pada eceng gondok lebih besar dibanding pada tempurung kelapa. Eceng gondok lebih mudah menyerap air sehingga kadar air pada eceng gondok mencapai $90 \%$ dari berat eceng gondok itu sendiri.

Briket yang mengandung kadar air yang tinggi akan mudah ditumbuhi jamur dan akan sukar dinyalakan [3].

\section{Kadar Zat Menguap}

Kadar zat menguap adalah zat yang dapat menguap sebagai hasil dekomposisi senyawasenyawa yang masih terdapat di dalam arang selain air. Kandungan kadar zat menguap yang tinggi di dalam briket arang akan menyebabkan asap yang lebih banyak pada saat briket dinyalakan. Tinggi rendahnya kadar zat menguap pada briket yang dihasilkan dipengaruhi oleh komposisi campuran bahan baku.

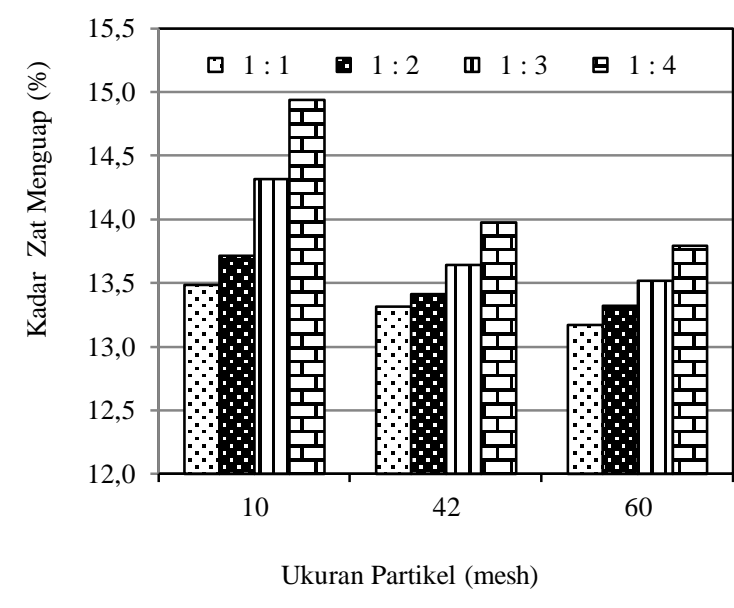

Gambar 4. Pengaruh Perbandingan Eceng Gondok dan Tempurung Kelapa Serta Ukuran Partikel Terhadap Kadar Zat Menguap

Pada Gambar 4 dapat dilihat kadar zat menguap terendah pada perbandingan eceng gondok dengan tempurung kelapa 1:1 pada ukuruan partikel 60 mesh yaitu $13,1700 \%$, sedangkan kadar zat menguap terbesar pada perbandingan 1:4 dengan ukuran partikel 10 mesh yaitu 14,9351\%.

Kadar zat menguap briket semakin meningkat seiring dengan semakin banyaknya penambahan tempurung kelapa. Hal ini disebabkan tempurung kelapa memiliki zat-zat yang mudah menguap. Kandungan zat menguap yang tinggi akan menimbulkan banyak asap pada saat briket dinyalakan.

Kadar zat menguap juga dipengaruhi oleh ukuran partikel briket, dimana semakin kecil partikel suatu briket maka kadar zat menguap pada briket tersebut akan semakin kecil, karena semakin kecil partikel briket maka kandungan briket yang menguap akan semakin sedikit pula.

\section{Uji Kerapatan}

Kerapatan menunjukkan perbandingan antara berat dan volume briket arang. Besar kecilnya kerapatan dipengaruhi oleh ukuran dan kehomogenan arang penyusun briket tersebut.

Pada Gambar 5 dapat dilihat nilai kerapatan briket terendah sebesar $0,8921 \mathrm{~g} / \mathrm{cm}^{3}$ terdapat pada perlakuan perbandingan eceng gondok dengan tempurung kelapa 1:1, sedangkan nilai kerapatan tertinggi yaitu $1,1254 \mathrm{~g} / \mathrm{cm}^{3}$ terdapat pada perlakuan perbandingan eceng gondok dengan tempurung kelapa 1:4.

Hal ini disebabkan pada ukuran briket 10 mesh partikelnya lebih besar sehingga kemampuan untuk merapat lebih sukar dan terdapat banyak rongga-rongga kosong untuk dilalui oksigen, tetapi lebih mudah terbakar, sehingga akan mempengaruhi laju pembakarannya yaitu akan cepat habis. Pada ukuran mesh 60 partikel relatif kecil sehingga 
mudah untuk merapat dan rongga-rongga kosong jauh lebih sedikit, tetapi lebih sukar untuk dibakar dan briket tersebut akan lebih lama habis bila dibakar. Pada penelitian ini digunakan tekanan pencetakan sebesar $1000 \mathrm{~kg} / \mathrm{cm}^{2}$.

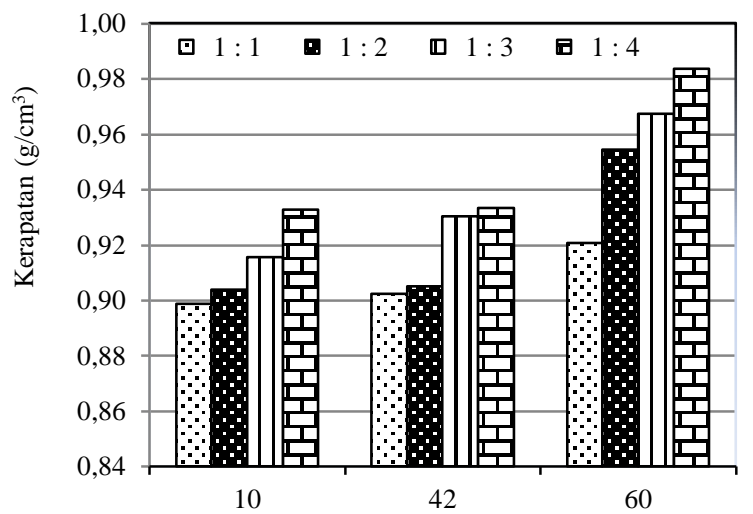

Ukuran Partikel (mesh)

Gambar 5. Pengaruh Perbandingan Eceng Gondok dan Tempurung Kelapa Serta Ukuran Partikel Terhadap Kerapatan Briket

\section{Uji Kekuatan Tekan}

Kuat tekan menunjukkan daya tahan suatu briket terhadap tekanan luar sehingga mengakibatkan briket tersebut pecah atau hancur. Semakin besar nilai kuat tekan berarti daya tahan briket semakin baik.

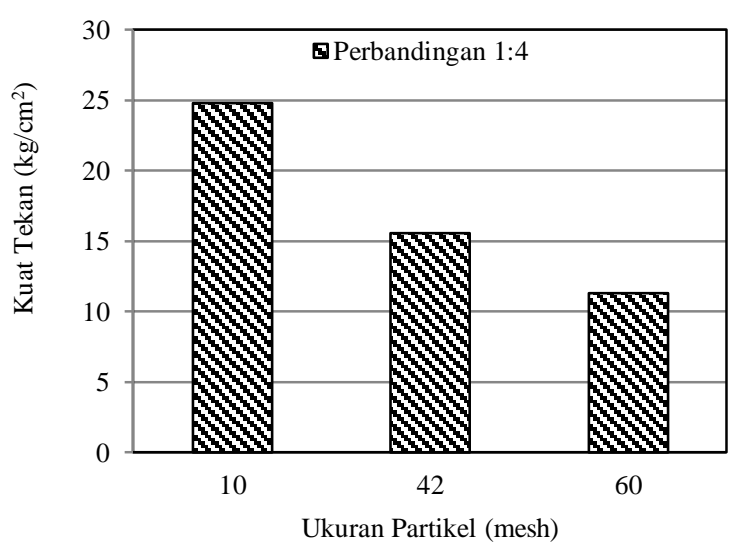

Gambar 6. Pengaruh Perbandingan Eceng Gondok dan Tempurung Kelapa Serta Ukuran Partikel Terhadap Kekuatan Tekan

Pada Gambar 6 dapat dilihat nilai kuat tekan terendah terdapat pada perbandingan eceng gondok dan tempurung kelapa 1:4 dengan ukuran partikel 60 mesh yaitu sebesar $11,3234 \mathrm{~kg} / \mathrm{cm}^{2}$ dan nilai kuat tekan tertinggi terdapat pada perbandingan 1:4 dengan ukuran partikel 10 mesh yaitu sebesar $24,7699 \mathrm{~kg} / \mathrm{cm}^{2}$. Pada penelitian ini hanya dilakukan pengujian nilai kuat tekan untuk perbandingan 1:4 saja pada ukuran partikel 10 mesh, 42 mesh, dan 60 mesh, sebab pada perbandingan ini dianggap sebagai perbandingan yang terbaik untuk setiap ukuran partikel dari nilai kalor, kadar abu, kadar air, zat

menguap, laju pembakaran, dan kerapatan pada briket.

\section{Laju Pembakaran}

Laju pembakaran merupakan penggambaran berkurangnya bobot briket per detik selama pembakaran. Pengurangan bobot yang semakin cepat memberikan laju pembakaran yang besar. Semakin besar laju pembakaran, maka nyala briket akan semakin singkat begitu juga sebaliknya.

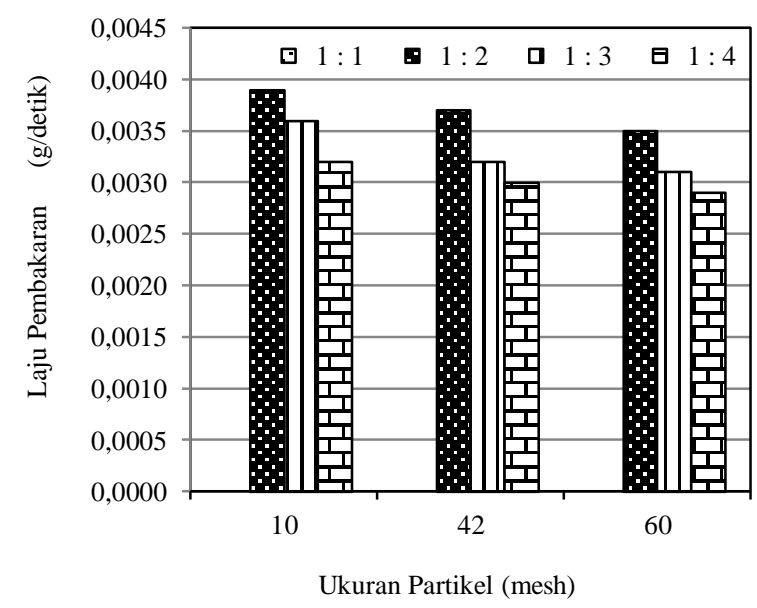

Gambar 7. Pengaruh Perbandingan Eceng Gondok dan Tempurung Kelapa Serta Ukuran Partikel Terhadap Laju Pembakaran

Pada Gambar 7 dapat dilihat nilai laju pembakaran terendah pada perbandingan eceng gondok dengan tempurung kelapa 1:4 untuk ukuran partikel 60 mesh yaitu 0,0028 g/detik, sedangkan nilai laju pembakaran terbesar diperoleh pada perbandingan 1:1 untuk ukuran partikel 10 mesh yaitu $0,0043 \mathrm{~g} /$ detik. Hal ini disebabkan oleh nilai kerapatan yang dihasilkan pada ukuran partikel 10 mesh, 42 mesh, dan 60 mesh berbeda, dimana pada partikel 60 mesh nilai kerapatannya lebih besar dibanding pada 10 dan 42 mesh, sehingga briket lebih lama habis.

Laju pembakaran di pengaruhi oleh kerapatan suatu briket, dimana semakin rapat suatu briket maka laju pembakarannya semakin lama atau lama habis bila dibakar, sebab semakin rapat suatu briket maka rongga udaranya semakin sedikit atau semakin sukar dilalui oksigen pada proses pembakaran.

Hasil penelitian ini juga menunjukkan bahwa semakin banyak tempurung kelapa di dalam briket maka akan semakin lama waktu pembakarannya sehingga laju pembakarannya semakin kecil. Hal ini disebabkan tempurung kelapa memiliki nilai kalor yang lebih tinggi dan kerapatan lebih besar 
dibandingkan eceng gondok, dimana semakin tinggi nilai kalor briket maka waktu pembakaran semakin lama.

\section{Kesimpulan}

Berdasarkan hasil penelitian, analisis karakterisasi dan pembahasan yang telah dilakukan terhadap perbandingan eceng gondok dan tempurung kelapa, maka dapat disimpulkan sebagai berikut :

1. Perbandingan eceng gondok dan tempurung kelapa terbaik pada penelitian ini adalah perbandingan 1:4 pada ukuran partikel 60 mesh dengan nilai kalor tertinggi 6851,7453 kal/g, kadar abu terendah $8,1918 \%$, kadar air terendah $1,0140 \%$, kadar zat menguap $13,7890 \%$, kerapatan tertinggi $0,9836 \mathrm{~g} / \mathrm{cm}^{3}$, laju pembakaran terendah $0,0029 \mathrm{~g} /$ detik, dan kuat tekan $11,3234 \mathrm{~kg} / \mathrm{cm}^{2}$.

2. Berdasarkan analisa ekonomi yang dilakukan total biaya produksi briket dari hasil penelitian yaitu sebesar Rp 11.689,24/kg. Untuk pembuatan briket dalam jumlah yang besar diperkirakan dapat mengurangi biaya produksi, sehingga harga jual dapat ditekan. Pembuatan briket ini berpotensi untuk mengurangi limbah eceng gondok dan tempurung kelapa yang dapat dimanfaatkan sebagai sumber energi alternatif.

\section{Daftar Pustaka}

[1] Arif F. Utomo dan Nungki Primastuti, Pemanfaatan Limbah Furniture Eceng Gondok (Eichornia Crassipes) di Koen Gallery Sebagai Bahan Dasar Pembuatan Briket Bioarang, Jurnal Teknologi Kimia dan Industri, Vol. 2, No. 2, hal. 220-225, 2013.

[2]. Dian Fatmawati dan Priyo H. Adiwibowo, Pembuatan Biobriket Dari Campuran Eceng Gondok dan Tempurung Kelapa Dengan Perekat Tetes Tebu, Jurnal Teknik Mesin, Vol. 03, No. 02, hal. 315-322, 2014.

[3] Djeni Hendra, Pemanfaatan Eceng Gondok (Eichornia Crassipes) Untuk Bahan Baku Briket Sebagai Bahan Bakar Alternatif , Jurnal Penelitian Hasil Hutan, Vol. 29, No. 2, hal. 189-210, Juni 2011.

[4] Kharis A. Rafsanjani, Sarwono, Roni Dwi Noriyanti, Studi Pemanfaatan Potensi Biomassa Dari Sampah Organik Sebagai Bahan Bakar Alternatif (Briket) Dalam Mendukung Progam Eco-Campus di ITS Surabaya, Jurnal Teknik Pomits, Vol. 1, No. 1, hal. 1-6, 2012.

[5] Nodali Ndraha, Uji Komposisi Bahan Pembuat Briket Bioarang Tempurung Kelapa dan Serbuk Kayu Terhadap Mutu Yang Dihasilkan, Skripsi, Progam Sarjana Fakultas Pertanian, Universitas Sumatera Utara, Medan, hal. 16-38, 2010.

[6] Rita D Ratnani, Indah Hartati, Laeli Kurniasari, Pemanfaatan Eceng Gondok (Eichornia Crassipes) untuk Menurunkan kandungan COD
(Chemical Oxygen Demond), pH, Bau dan Warna Pada limbah Cair Tahu, Jurnal Momentum Vol 7, No.1, hal. 41-47, April, 2011.

[7] Suyitno, Pengaruh Ukuran Partikel Terhadap Karakteristik Pembakaran Biomasa, Skripsi, Universitas Sebelas Maret, Surakarta, Indonesia, hal. 14-17, 2005. 